\author{
A. Vasiliev · M. Kanevskiy · G. Cherkashov \\ B. Vanshtein
}

\title{
Coastal dynamics at the Barents and Kara Sea key sites
}

Received: 22 September 2004/ Accepted: 29 April 2004/Published online: 15 December 2004

(C) Springer-Verlag 2004

\begin{abstract}
The results of permafrost and coastal dynamics investigations at four key sites on the shores of the Kara and Barents Seas are discussed. Three ACD key sites, Marre-Sale, Shpindler, and Kolguev, characterize areas with active thermal erosion; key site Cape Bolvansky is found on a relatively stable coast. It is found that the coastal retreat rate has spatial and temporal variability, which is typical of the entire Arctic coast. Coastal deposits on the Kara and Barents Seas have a low organic carbon content. Annual input of material into the Kara Sea resulting from coastal degradation reaches 35-40 million $t$, including about 7.5 million $t$ of ice, 0.35 million $\mathrm{t}$ of organic carbon, and 0.3 million $\mathrm{t}$ of soluble salts.
\end{abstract}

\section{Introduction}

The evolution of Arctic seacoasts is a result of the interaction between the Arctic Ocean and continental land masses. Investigations of coastal dynamics have made possible a broader understanding of the history and current trends in the development of seacoasts, including the development of permafrost as one of the main components of Arctic environments.

This revised version was published online January 2005 with corrections to the title of the article.

A. Vasiliev $(\bowtie) \cdot$ M. Kanevskiy

Earth Cryosphere Institute, SB RAS,

Vavilova 30/6, Moscow, 117982, Russia

E-mail: z_v_a_a@dio.ru

Tel. + 7-095-1359920

Fax: + 7-095-1356582

G. Cherkashov · B. Vanshtein

All-Russia Research Institute for Geology and Mineral Resources of the World Ocean, St. Petersburg, Russia
Permafrost deposits are destroyed along Arctic coasts, where submerged, frozen subaerial coastal deposits are subjected to transformation under the sea in addition to their thawing. This process releases solid sediments, dissolved chemical compounds, organic carbon, and pore gases into the sea. Available estimates show that the input of solid sediments from the destruction of shores into the Arctic basin is considerable and comparable to or even exceeds sediment discharge by large rivers (Are 1998; Rachold et al. 2000, 2003; Romankevich and Vetrov 2001; Stein and Macdonald 2003).

The dynamics of Arctic coasts are dictated by a combination of hydrolithodynamic processes operating in the sea and by cryogenic coastal processes operating on land. Over long time periods, the coastal system is in equilibrium with respect to its mass and energy.

\section{Goals of the study}

The main goal of our work is to study permafrost and the dynamics of seacoasts at ACD key sites in the western sector of the Russian Arctic.

The particular tasks are as follows:

- the study of landscape structure at the key sites;

- detailed description of the morphology of shore cliffs and sub-sea slopes and the development of digital terrain models;

- the study of the geological and geocryological structure of the key sites;

- the study of the lithological and chemical composition of the deposits and the ice content in them;

- the analysis of the organic carbon content in coastal sediments;

- detailed monitoring of the dynamics and particular mechanisms of coastal destruction;

- the collection of data on hydrometeorological features of the study area, including data on sea waves;

- the development of a computerized database to store and analyze the information obtained. 


\section{Methods}

During the first stage of the study, we performed a literature review that encompassed the environmental conditions, geology, geocryology, and coastal dynamics of the potential key sites (Leibman et al. 2000; Vasiliev and Rogov 2001; Vasiliev et al. 2001; Vasiliev 2003). Aerial photos of coasts obtained in different years were analyzed. Preliminary data on landscape conditions in the coastal areas were obtained during interpretation of these photos, and representative areas were selected to support the organization of the coastal dynamics monitoring program. A comparison of photos obtained in different years made it possible to estimate the rate of coastal retreat.

Fieldwork at the selected key sites was aimed at a detailed study of their geological and geocryological structure. Samples recovered from deposits at the key sites were analyzed for lithological composition, and the quantities of salts, ice, and organic carbon were determined.

Observational transects with benchmarks were installed at the key sites, oriented perpendicularly to the coastline. The distance between transects varied from 20 to $50 \mathrm{~m}$. The length of coastline outfitted for this type of profiling work varied from 1 to $4.5 \mathrm{~km}$ at different key sites.

Measurements of the exact position of the upper edge of shore cliffs have been performed annually, at the end of the warm season. As coastal geosystems are generally balanced, the retreat rate of cliff edges corresponds approximately to the coastal retreat rate.

Beginning in 2001, precise geodetic measurements of the terrestrial relief at the key sites were obtained using an electronic tachymeter (DTM-350). The error of measurements does not exceed $0.1 \mathrm{~m}$. The positions of the shoreline (accounting for tidal cycles) and the upper edge and foot of the cliff were determined using GPS technology (GeoExplorer 3).
The relief of the littoral slope from the shoreline out to the $10-\mathrm{m}$ isobath was determined with the use of a NAVSTAR GPS and a digital echo sounder. Measurement error of underwater relief is $0.1 \mathrm{~m}$.

\section{Study areas}

The monitoring of coastal dynamics in the Kara and Barents Seas is conducted at four key sites (Fig. 1): Marre-Sale $\left(69^{\circ} 43^{\prime} \mathrm{N}, 66^{\circ} 45^{\prime} \mathrm{E}\right)$ on the western coast of Yamal Peninsula, Cape Shpindler $\left(69^{\circ} 43^{\prime} \mathrm{N}\right.$, $62^{\circ} 42^{\prime}$ E) on the northern coast of Yugor Peninsula, Cape Bolvansky $\left(68^{\circ} 18^{\prime} \mathrm{N}, 54^{\circ} 30^{\prime} \mathrm{E}\right)$, and the western coast of Kolguev Island $\left(69^{\circ} 15^{\prime} \mathrm{N}, 48^{\circ} 18^{\prime} \mathrm{E}\right)$. The choice of these key sites was dictated by our desire to represent the most typical conditions of seacoast destruction in the western Russian Arctic. This choice was based on detailed analysis of geological structure, permafrost features and other conditions of the study areas.

All key sites are in the zone of continuous permafrost with a thickness of more than $100 \mathrm{~m}$. Except for Cape Bolvansky, they are found on actively eroded coasts. Cape Bolvansky, at the mouth of the Pechora River, is protected from the action of the open sea by a long spit and a series of small accumulative isles. This area has relatively stable coasts.

The Marre-Sale key site is situated in an area typical for the western coast of the Yamal Peninsula. This site has seen the most detailed study, such that it may be considered to be a reference site for the western sector of the Russian Arctic. Studies at the other sites have been aimed at revealing local peculiarities of the geological and geocryological conditions, as well as the hydrodynamic parameters of the sea, and their effect on the dynamics of seacoasts.

General data on the key sites are listed in Table 1.
Fig. 1 Location of the key sites (1 Marre-Sale; 2 Cape Shpindler; 3 Cape Bolvansky; 4 Western shore of the Kolguev Island)

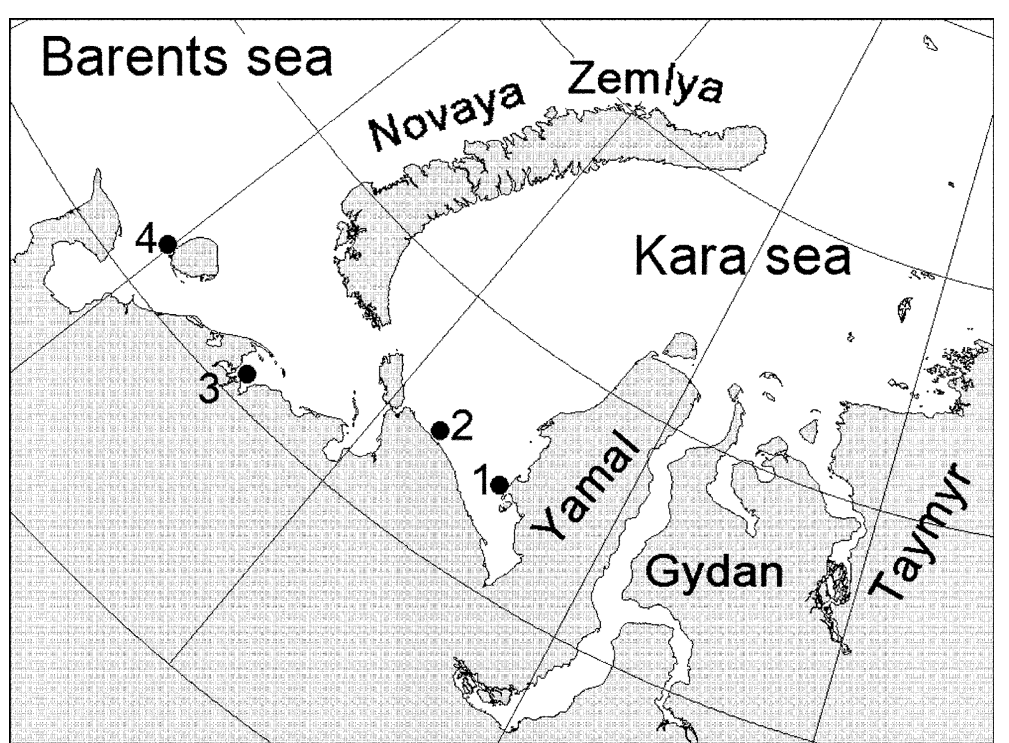




\section{Results}

\section{Marre-Sale}

The Marre-Sale key site is located in a typical tundra environment. Geomorphologically, the coastal zone at this site belongs to the second and third sea terraces, whose surface is dissected by modern cryogenic processes. Absolute heights vary from 10 to $30 \mathrm{~m}$ a.s.l. Marine clay lies at the base of the geological section of the coast near the Marre-Sale Station. The surface of the clay layer is eroded and uneven. Continental sands overlie the clay layer (Vasiliev et al. 2001). The ice content of these deposits varies considerably, ranging from 20 to $60 \%$ by volume. Ice wedges and massive ice beds are found in the section.

In 1978, observational sections with benchmarks were installed along a $4.5 \mathrm{~km}$ stretch of the coast to the south of the Marre-Yakha River mouth. Overall, more than 60 sections spaced $20-100 \mathrm{~m}$ from one another were made (Pavlov et al. 1995). Starting in 1979, at the end of each summer season, regular measurements of the distance from the cliff edge to the nearest benchmark have been taken at these sections. This record has made it possible to calculate the retreat rate for the cliff edge.

In 2001 and 2002, a detailed survey of the relief of onshore and offshore parts of the key site was conducted, and exact positions of the shoreline, the foot of the cliff, and the cliff edge were determined.

Geological and geocryological surveys of coastal deposits were conducted in 1998-2002 (Forman et al. 1999; Vasiliev and Rogov 2001; Vasiliev et al. 2003). Samples of coastal sediments were collected to determine their lithological composition and the content of ice and organic carbon.

The results of these long-term (more than 20 years) investigations have been put into a computerized database using Paradox 5.0 software for Windows. Along with this, a digitized model of the relief of the offshore and onshore parts of the key site has been created using the HYPACK software package.

In general, the relief of the sea bed is rather even. Isobaths are parallel to the shoreline. The approximate average distance to the $10-\mathrm{m}$ isobath is $2,800 \mathrm{~m}$, and the sea-bed slope equals 0.003 . Wave impact on the sea bed is traced to a depth of 6-7 m; deeper, the sea-bed surface gradually lowers down to a depth of 8-10 m. Beyond this, at a depth of 10-11 m, a well-marked bend of the sea bed is seen. This bend is the result of geology and not related to the impact of waves.

Along with a detailed survey of the sea-bed topography at the key site with active thermal erosion of the coast, we have also surveyed a profile of the sea bed along a part of the shore at which both erosional and aggradational processes are observed beyond the key polygon, in the delta of the Marre-Yakha River. The width of the delta is about $2 \mathrm{~km}$, and its surface height is about 2-3 $\mathrm{m}$ a.s.l. Erosional processes develop in the frontal seaward part of the delta.

A comparison of sea-bed profiles for these two sites shows that the offshore slope at the site with active thermal erosion is steeper than that at the site with erosional and aggradational processes. The difference is traced down to a depth of 6-7 m, i.e., to the maximum depth of wave action. Deeper, the two profiles do not differ much.

The organic carbon content was determined in 11 clay samples and six sand samples. The $\mathrm{C}_{\text {org }}$ content in the sand and clay averages 0.7 and $0.9 \%$, respectively.

The rate of coastal retreat varies both spatially and temporally. Of the profiles monitored, the largest retreat observed over the 24-year period of record was $69.7 \mathrm{~m}$, the smallest, $13 \mathrm{~m}$, and the average value is $41.5 \mathrm{~m}$. This gives an average annual retreat rate of $1.7 \mathrm{~m} /$ year.

Figure 2 shows the position of the cliff edge for several different years. As seen from this figure, the retreat of the northern (left) part of the cliff is greater than that of the southern part. At the same time, spatial and temporal variability in the intensity of retreat within the northern part of the shore is considerable; this is indicated indirectly by a great sinuosity of the shoreline. We attribute this phenomenon to a higher ice content in coastal deposits within the northern part of the key plot (Vasiliev et al. 2001).

While the average rate of retreat is $1.7 \mathrm{~m} /$ year, an activation of thermal erosion was observed in 1989 1990, causing the rate to reach $3.3 \mathrm{~m} /$ year. The minimal

Table 1 Metadata summary for key sites on the coasts of Barents and Kara Seas

\begin{tabular}{|c|c|c|c|c|c|c|}
\hline Sea & Key site & Geomorphology & $\begin{array}{l}\text { Cliff } \\
\text { height }(\mathrm{m})\end{array}$ & Deposits & $\begin{array}{l}\text { Method for determining } \\
\text { of the coastline retreat }\end{array}$ & $\begin{array}{l}\text { Observation } \\
\text { period }\end{array}$ \\
\hline \multirow[t]{2}{*}{ Kara Sea } & Marre-Sale & $\begin{array}{l}\text { Third and second } \\
\text { flat sea terraces }\end{array}$ & $15-30$ & Clays and sands & AP, DGPS, BM, LT & $1978-2003$ \\
\hline & Cape Shpindler & $\begin{array}{l}\text { Hilly-ridged } \\
\text { glaciomarine plain }\end{array}$ & $20-45$ & Clays and sands & $\mathrm{AP}, \mathrm{LT}$ & 1999-2002 \\
\hline \multirow[t]{2}{*}{ Barents Sea } & Cape Bolvansky & $\begin{array}{l}\text { Gently hilly } \\
\text { glaciomarine plain }\end{array}$ & $5-30$ & Loams, sands, peat & $\mathrm{BM}$ & 1999-2003 \\
\hline & $\begin{array}{l}\text { Western shore } \\
\text { of Kolguev Island }\end{array}$ & $\begin{array}{l}\text { Gently sloping } \\
\text { marine plain }\end{array}$ & $40-50$ & $\begin{array}{l}\text { Clays, pebbly } \\
\text { loams, sands }\end{array}$ & AP, DGPS & 2002 \\
\hline
\end{tabular}

$A P$ comparison of aerial photos; DGPS differential GPS; $B M$ annual observation of sections with benchmarks; $L T$ measurements with a laser theodolite 
Fig. 2 Temporal dynamics of the coastline retreat at the Marre-Sale key site

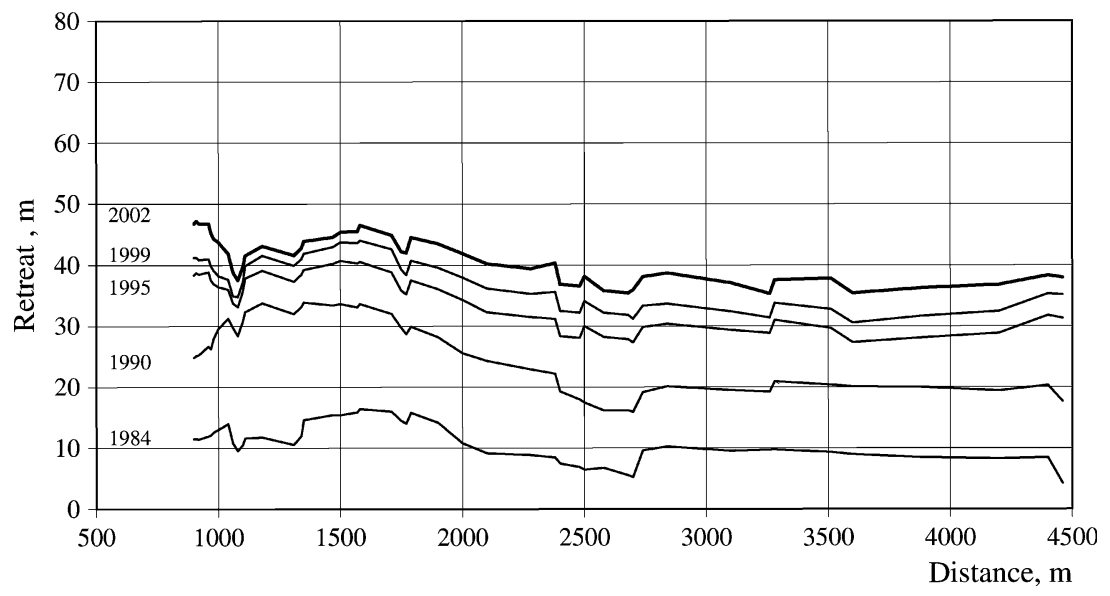

rate $(0.5 \mathrm{~m} /$ year $)$ was observed in 1999 . We believe that the average retreat rate of the coast is characteristic for the western coast of the Yamal Peninsula, most of which has a structure similar to that of the Marre-Sale coast.

The maximal rates of retreat were observed in the summers of 1989 and 1990, which were characterized by the highest mean summer air temperatures observed during the 24-year monitoring period. Though it is obvious that the rate of thermal erosion is connected with the summer air temperatures, at present time we cannot establish a correlation between these two parameters.

The main cause of coastal destruction in these permafrost areas is the disturbance of the equilibrium profile caused by the thermal erosion of the cliff base and the destruction of the underwater slope. Slope processes initiated by the destruction of the cliff base cause the retreat of the upper part of the cliff.

The retreat rate is closely connected with the wave energy. The total wave energy can be calculated as the sum of energies in every particular direction multiplied by correction coefficients for the orthogonal direction (Hequette and Barnes 1990). We have calculated conventional values of the annual energy of sea waves for each particular direction as the product of the squared height of waves and the duration of waves coming to shore in a given direction. The calculated wave energy values measured in [meter square day] are called "conventional" energy values because they do not take into account the lengths of waves of different heights coming to shore from a given direction (these data are not available from observational records at the Marre-Sale weather station). Data on conventional wave energy for the years of observation, including the portion of this energy related to storms, are shown in Fig. 3 (Vasiliev et al. 2001).

The relationship between the rate of coastal retreat and the conventional wave energy is given in Fig. 4 (Vasiliev 2003). This relationship is very close: the correlation coefficient between the wave energy and the retreat rate reaches 0.8 . Thus, we can conclude that
Fig. 3 Temporal changes in the total energy of sea waves and storms component, Marre-Sale key site ( 1 Total wave energy, $\mathrm{m}^{2} *$ days; 2 Energy of storms, $\mathrm{m}^{2} *$ days)

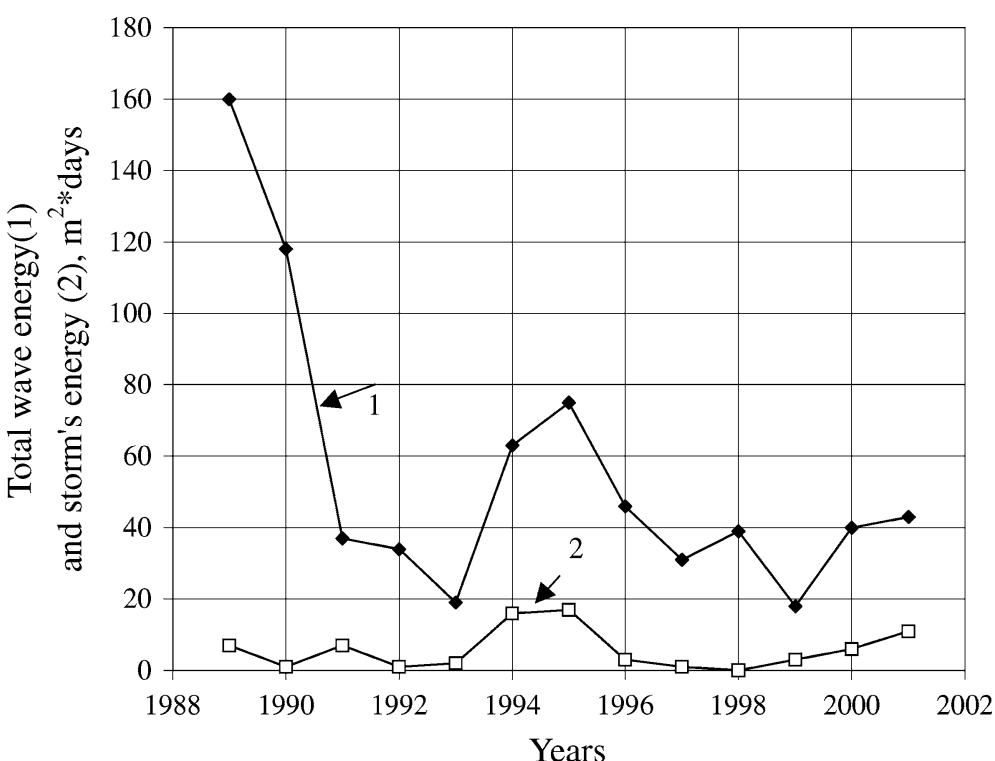


Fig. 4 Cliff edge retreat rate versus the total wave energy, Marre-Sale key site (Vasiliev 2003)

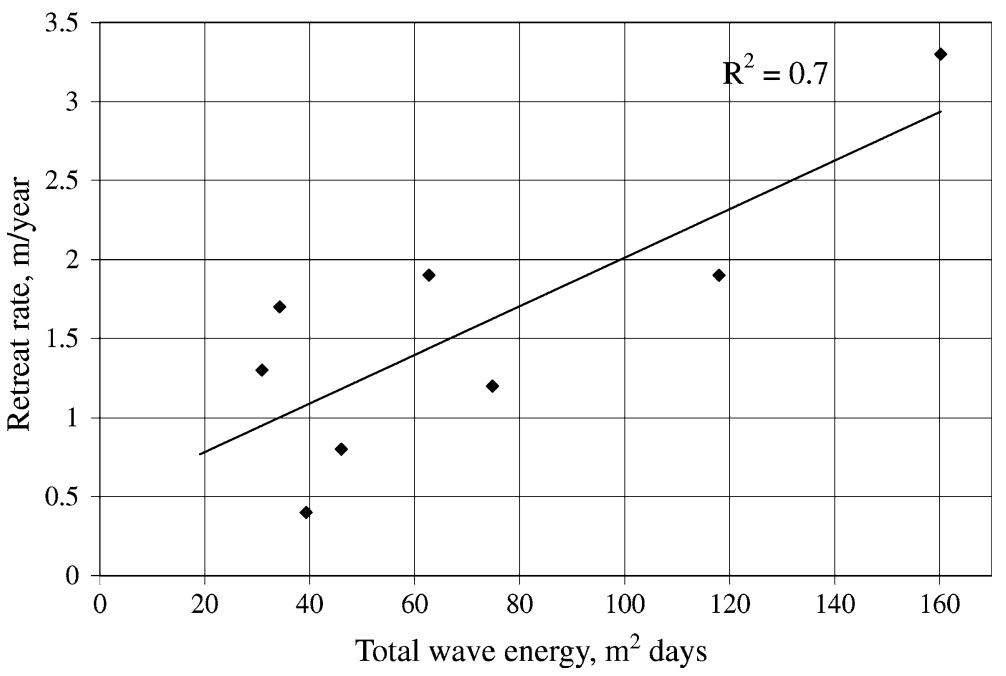

the wave erosion at the base of the cliff initiates the whole complex of processes leading to the cliff edge retreat.

It is necessary to note that the approximation line (Fig. 4) does not go through the origin, but instead crosses the ordinate axis at a point where the retreat rate reaches $0.4 \mathrm{~m} /$ year. This indicates that, in the absence of wave action, the coastal retreat rate owing to thermal denudation and the action of slope processes can reach $0.4 \mathrm{~m} /$ year. We may consider this value as characteristic not only for the Marre-Sale key site but for all of the Western Yamal coastline, most of which shares similar climatic and geocryological conditions.

Currently there is some debate about the role of storms in coastal erosion, including permafrost coasts. Our data make it possible to evaluate the effect of storms on coastal erosion. Figure 5 illustrates the relationship between the coastal retreat rate and the number of days with storms. This relationship is positive but very weak (correlation coefficient 0.4), i.e., storms affect the processes of coastal erosion, but their influence is less significant than has been previously suggested.

It can be concluded that the contribution of storms with wave heights of more than $1 \mathrm{~m}$ to the total conventional wave energy does not exceed $25 \%$ (Fig. 3). The increase of retreat rate in stormy seasons (as assessed from Fig. 4) reaches approximately $20 \%$. Therefore, we may conclude that the role of storms is less significant in comparison with the continuous action of small waves. Coastal retreat is caused mostly by continuous wave action by waves of less than $1 \mathrm{~m}$ height, which disturbs the equilibrium of the coastal cliff and lead to the activation of thermal erosion.

For verification purposes, our measurements of coastal retreat were compared with coastal retreat rates interpreted from aerial photos for 1947 and 2001. As interpreted from the aerial photos, the retreat rate for different parts of the coast varied from 1.4 to $2.0 \mathrm{~m} / \mathrm{year}$, with an average value of $1.7 \mathrm{~m} /$ year. According to the results of precise surveys of coastline position in 2001
Fig. 5 The coastal retreat rate versus the number of days with storms, Marre-Sale key site

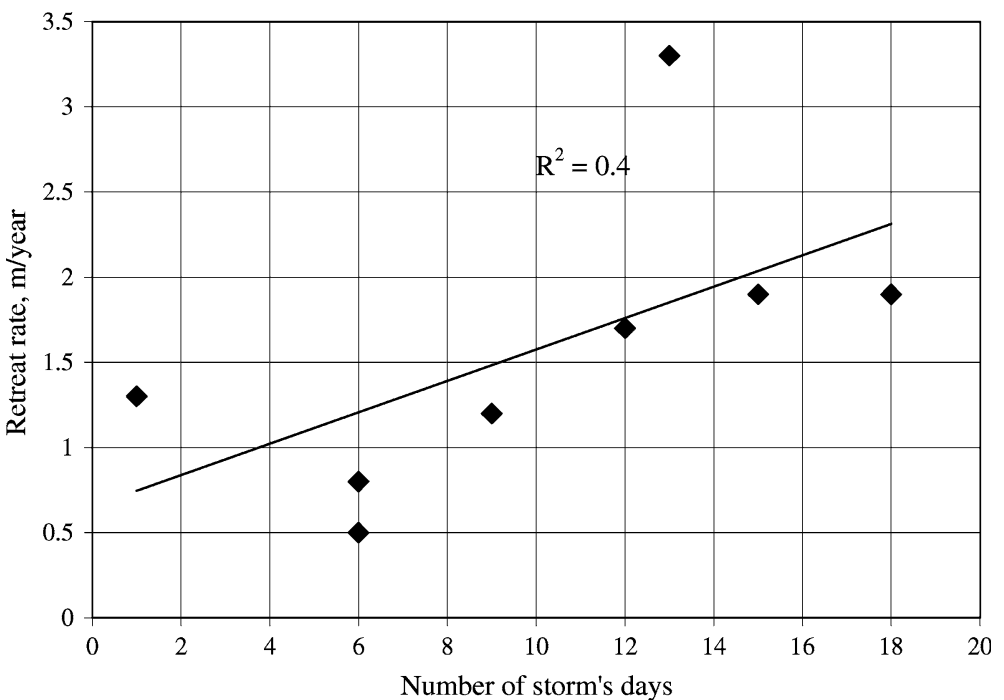


and 2002 , the retreat rate is $1.53 \mathrm{~m} /$ year, which is comparable with the results of measurements at observational sections in the same years $(1.7 \mathrm{~m} /$ year $)$. Thus, all methods applied to assess the rate of coastal retreat for both long-term periods and for particular years give approximately the same results.

\section{Cape Shpindler}

The coast of Yugor Peninsula in the area of Cape Shpindler represents a hilly, ridged plain with heights of 40-55 $\mathrm{m}$ a.s.1. The height of the coastal cliff varies from 20 to $45 \mathrm{~m}$. The area lies within the zone of typical tundra. This area was selected as a key site for our study because of the widespread occurrence of massive ice beds in the coastal deposits. This is one of a few areas along the Russian Arctic coast where the effect of ice beds on the dynamics and mechanisms of coastal erosion is pronounced.

During the first stage of the study, we carefully examined the morphology of the cliff and sea bed and their geological and geocryological peculiarities. At the key site, the height of the cliff reaches $30-45 \mathrm{~m}$, and its slope is about $60^{\circ}$.

The sea-bed slope near the shore is relatively steep. At a distance of $40 \mathrm{~m}$ from the shore, an underwater bar of $0.5-1.0 \mathrm{~m}$ height is formed under the impact of wave action and along-shore current. The wave action on the sea bed terminates at a depth of 6-7 m. The distance to the $10 \mathrm{~m}$ isobath is approximately $1,500 \mathrm{~m}$, and the general slope of the sea bed equals 0.0067 . A relatively steep offshore slope may be the result of a tectonic scarp of relatively high amplitude lying roughly parallel to the shoreline at a distance of several kilometers from the shore.

The cliff is composed of marine and glaciomarine clays with sandy interlayers. Initially more extensive marine clays have since been partly or completely transformed by the action of an ice sheet (Goldfarb and Ezhova 1990). The transformed part of the clay deposits, which bear evident features of glaciation, is referred to as a diamicton. Sandy interlayers are interpreted as glaciofluvial deposits (Manley et al. 2001). Our investigations have demonstrated that the sea stage and marine deposits played a significant role in the geological development of this area and in the formation of the geological and geocryological peculiarities of coastal deposits.

Massive ice beds have a length of $300-500 \mathrm{~m}$ and more with thicknesses reaching $20 \mathrm{~m}$. The distance between separate beds varies from several hundred to several thousand meters. There are numerous features attesting to the segregational and injectional mechanisms of the formation of these ice beds (Leibman et al. 2000).

The cryogenic structure of the coastal deposits is variable, and ranges from massive to layered with lenses, and in some places, it is lattice-like. The ice content typically varies from 20 to $25 \%$ by volume, and can range up to $40 \%$.

During the survey, we collected more than 20 samples of coastal deposits for organic carbon sampling. The $C_{\text {org }}$ content in coastal sediments varies from 0.2 to $3.5 \%$, with an average of $1.0 \%$ in clay and $0.1 \%$ in sand.

In 2001, 20 observational sections with benchmarks were installed along a $2 \mathrm{~km}$ section of shoreline. The coastal retreat was assessed via comparing the coastline position on an aerial photo from 1947 with its modern position determined by geodetic survey. Measurements show that the total retreat in 54 years varies from 50 to $87 \mathrm{~m}$ (Kizyakov 2002), giving an average rate of coastal retreat in this period of $1.1 \mathrm{~m} /$ year.

\section{Cape Bolvansky}

Cape Bolvansky is found to the east of the Pechora River mouth. This site was selected for the study because it characterizes an area protected from the direct action of waves by a long narrow spit extending far into the sea and forming a vast lagoon (Pechora Bay, Fig. 1). Thus, it characterizes the lagoon type of coast.

The coastal plain with gently sloping hills has a height of 25-30 $\mathrm{m}$ a.s.1.; the plain is dissected by deep ravines, lake depressions, and small creek valleys. It lies within the southern taiga zone.

The plain is composed of marine and glaciomarine sediments with a predominance of loams and cobbled sandy interlayers and lenses. Polygonal peatlands with a thickness of $1-5 \mathrm{~m}$ are found in depressions.

The height of the cliff ranges from 20 to $30 \mathrm{~m}$; its angle depends on the type of geological section. In areas composed of peat, the cliff is almost vertical, a sandy cliff has an angle of up to $40^{\circ}$, and sandy loamy cliffs are inclined from 20 to $44^{\circ}$.

A characteristic feature of this key site is a very gentle slope of the sea bed. At high tide, the width of the beach is less than $10 \mathrm{~m}$, whereas at low tide, it exceeds $300 \mathrm{~m}$. The slope gradient is about 0.0003 . The sea bed is virtually flat, which is typical of the stable type of coasts.

The ice content in the loamy sediments is about 30 $40 \%$ by volume; in sands, $20 \%$; and in peat, $30-50 \%$. The $C_{\text {org }}$ content in the peat samples is about $82 \%$; in sands, $0.3 \%$; and in loams, $0.8 \%$.

In 2000 , ten observational sections with benchmarks were installed perpendicular to the shore line at intervals of about $1 \mathrm{~km}$. Measurements of cliff edge retreat were taken in September 2001 and 2002. The maximum retreat rate reached $0.4 \mathrm{~m} /$ year; the minimum retreat was zero. The average retreat rate did not exceed $0.1 \mathrm{~m} /$ year. The impact of waves on the toe of the cliff was seen only at some portions of the cliff. Thus, in the last 2-3 years, evidence of the activation of thermal erosion was not observed at this key site. At present, the inclination of the cliff slope is decreasing and the coastal landforms have attained an equilibrium state 
under the action of water and wind erosion, slumps, landslides, and thermal denudation. It is important to note that these processes are not connected with wave action.

\section{Western shore of Kolguev Island}

This key site was established in 2002 and lies within a typical tundra subzone. It is a glaciomarine coastal plain dissected by erosional and cryogenic landforms. The coastal cliff reaches heights of $45 \mathrm{~m}$ with a slope that exceeds $60^{\circ}$. A peculiar feature of this site is a low ice content in the deposits at the base of the cliff. At the same time, ice beds are present in the middle part of the geological section in some areas. Most likely, this represents the westernmost point of massive ice bed occurrence in the Russian Arctic. Thus, the study of coastal erosion at this key site makes it possible to understand the character of this process for coastal areas possessing both low and high ice contents.

In the first stage of study, we examined the relief of the offshore and onshore parts of the plot and their geological and geocryological structure and sampled coastal deposits to determine their ice and organic carbon contents. The cliff morphology is relatively stable; it is complicated by thermokarst cirques and hollows developed under the impact of water erosion.

The sea-bed slope has a complicated relief. It is steep near the shore and a submerged bar with a height of 1.5$2.0 \mathrm{~m}$ is found at a distance of $70-100 \mathrm{~m}$ from the shoreline. The sea-bed surface is complicated by hummocks and local depressions that become more distinct at greater depths. Isobaths have a complex folded shape. The development of this type of sea-bed topography may be connected with the deficit of sandy sediments that usually smooth the surface. This deficit occurs because there is a low sand content in the coastal deposits (which are predominantly clay) and because sand particles are actively removed by strong alongshore currents.

Immediately near the shoreline, the sea-bed inclination is steep at 0.025 , and the average inclination of the sea bed is also relatively steep at 0.0055 . These values exceed typical values for coasts subjected to thermal erosion.

Coastal deposits are composed of three (from bottom to top) suites (Velikotsky 1998):

- compact light gray clay with inclusions of cobbles and gravel;

- fine-grained light gray sands with inclusions of massive ice beds;

- grayish brown loams with interlayers and lenses of fine-grained sands and with inclusions of pebbles and shells of sea mollusks.

The layer of compact and dry clay has a massive cryogenic structure with rare subvertical ice schlieren. The ice content does not exceed $10 \%$ by volume.
Overlying sands also have a massive cryogenic structure; however, in the upper part of the section, they contain lenses and interlayers of massive ice with thicknesses from 0.5 to $2.0 \mathrm{~m}$ ( $1.0 \mathrm{~m}$ on the average). The total ice content (with ice beds) of the sandy layer reaches $25-30 \%$ by volume. The ice content of the upper layer of grayish brown loam reaches $20-30 \%$ by volume.

Thus, the lower part of the geological section subjected to wave action at this key site is characterized by a low volumetric ice content. Because of this, collapse phenomena affecting large blocks of coastal sediments are the major mechanisms of the destruction of the cliff. In the area with ice beds, relatively shallow cirques are formed. Sediments thawed out within these cirques and saturated with water flow down forming alluvial fans on the shore.

The destruction of the coastal cliff is accompanied by the accumulation of cobble and pebble material on the bench, which acts as a bumper, protecting the cliff from wave action. The $C_{\text {org }}$ content in the coastal sediments varies from 0.7 to $1.2 \%$.

Instrumental measurements of the cliff retreat rate have yet to be performed. A comparison of aerial photos obtained in 1948 and 1969 with the DGPS data obtained in 2002 made it possible to gain preliminary estimates of the retreat rate. The maximum rate is $3.5 \mathrm{~m} /$ year; the minimum, $0.6 \mathrm{~m} /$ year; and the average, $2.0 \mathrm{~m} /$ year.

\section{Discussion}

A comparison of sea-bed profiles from the key sites under investigation shows that the sea-bed slope at Cape Bolvansky corresponds to a stable coastal type with a low retreat rate. Data on the morphology of the cliff and measurements of its retreat rate further confirm the stability of this coast. Sea-bed profiles at the other three sites correspond to those typical of the coasts subjected to active thermal erosion (Fig. 6).

The gentlest slope was recorded off-shore of the Marre-Sale site. Its inclination near the shore is 0.08 and the average inclination (to $10 \mathrm{~m}$ depth) is 0.003 . Waves affect the sea bottom to a depth of 6-7 m. Off-shore slope development is subject to a large input of sand, which tends to smooth the sea-bed relief.

On the Western shore of Kolguev Island, the average inclination of the sea bed is somewhat higher, at 0.004 , whereas the inclination near the shore is lower, at 0.06 . Thus, according to their morphological characteristics, the offshore slopes at the Marre-Sale and Western Kolguev key sites are relatively similar to one another. The differences in the rates of coastal erosion at these sites are explained by differences in the lithological composition and the ice content of coastal deposits. Coasts of the Kolguev Island site are composed of compact clay sediments with a low ice content that are relatively resistant to wave erosion and other destructive processes. The development of cobbly and pebbly riprap near the foot of the cliff protects it from wave action. 
Fig. 6 Profiles of sea-bed slopes at the key sites

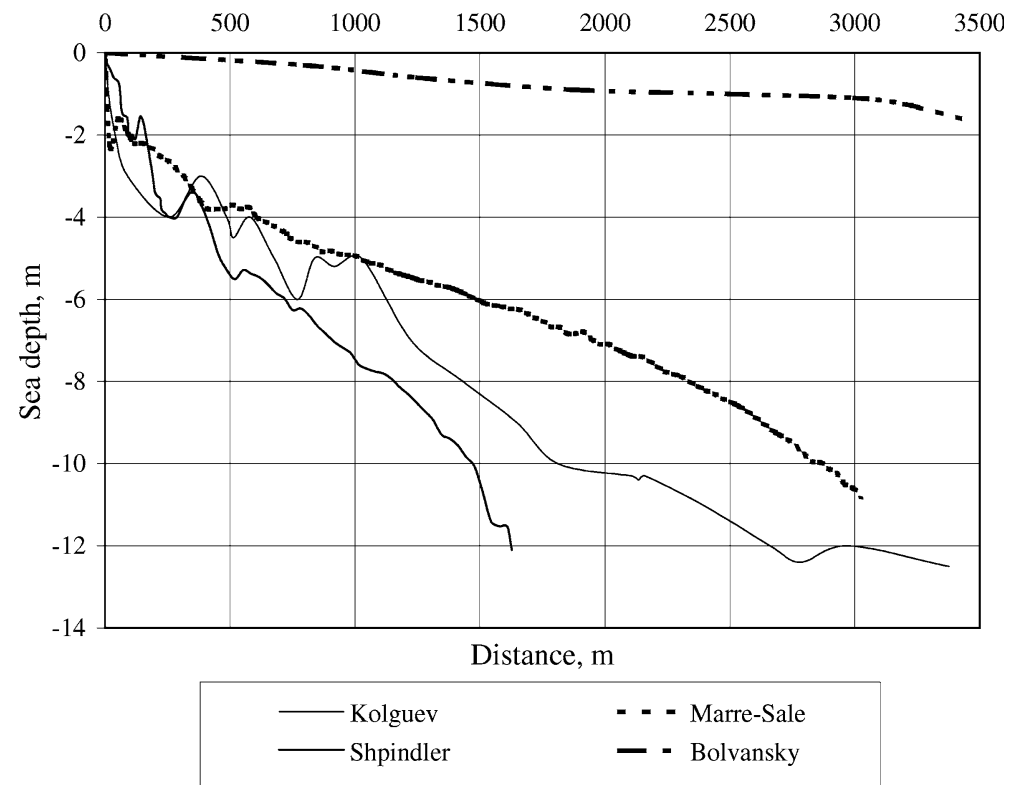

The offshore slope is formed under conditions of a deficit of sandy material, and the surface topography of the sea bed is uneven, with numerous hummocks and depressions. The depth of penetration of wave action reaches $8-10 \mathrm{~m}$.

The maximum steepness of the underwater slope is typical of the Shpindler key site, which is affected by a tectonic scarp in the sea, several kilometers from the shore. The average inclination is 0.007 , reaching 0.02 near the shore. The action of waves may be traced to a depth of $6 \mathrm{~m}$.

A direct comparison between retreat rate data and information on the morphology of offshore slopes shows that there is no direct relationship between slope steepness and coastal retreat rate. The latter is also a function of the peculiarities of the geological structure and the ice content of coastal deposits, tectonic factors, and hydrodynamic parameters of the sea.

The development of cryogenic processes on cliffs is largely controlled by geological structure and the ice content of coastal deposits. Collapse phenomena develop on those parts of the cliffs that are composed of sandy sediments with low ice content. Thermal denudation and viscous flow of water-saturated thawed material predominate in areas composed of clayey sediments with high ice content. A unique situation is observed in areas where coastal deposits contain massive ice beds. In this case, for relatively long periods (up to 10 years) the destruction of the cliff is a result of thermal denudation processes and is not connected with the coastal retreat. Thermokarst cirques develop on the surface of the cliff, the size of which depends on the extent and thickness of ice beds.

The specific destructive processes at work vary with time, because the retreating coast exposes parts of coastal plains with varying geology and ice content. Another important factor affecting the rate of retreat processes is wave action. After heavy and lengthy storms, deep wave-cut niches are formed at the foot of the cliff. Their development leads to the collapse of large blocks of coastal material followed by their gradual washing out by the sea.

Results from the analysis of $C_{\text {org }}$ content shows it is present in low amounts in coastal deposits within the western sector of Russian Arctic. In marine and glaciomarine sediments composing the coasts of Kara and Barents Seas, the $C_{\text {org }}$ content usually does not exceed $1 \%$.

The reserves of $C_{\mathrm{org}}$ in the tundra gleyed soils, which is the most widespread material in the region, are about $10 \mathrm{~kg} / \mathrm{m}^{2}$. Peat bog soils contain much more carbon (up to $35 \mathrm{~kg} / \mathrm{m}^{2}$ ), but they occupy relatively small areas. On average, it may be assumed that the organic carbon content in the soils of the coastal zone of the Kara and Barents Seas is about $10-12 \mathrm{~kg} / \mathrm{m}^{2}$.

As mentioned, the most detailed and long-term investigations into coastal dynamics have been performed at the Marre-Sale station. Data from this key site make it possible to estimate temporal variations in the rate of coastal retreat. The lowest observed retreat rate at this key site was $0.5 \mathrm{~m} /$ year, observed in 1978 and 1999, and the greatest, observed in 1989 and 1990, was $3.5 \mathrm{~m} /$ year (Fig. 7). The average rate for the entire period of observation is $1.7 \mathrm{~m} /$ year. It is interesting to note that temporal variations in the coastal retreat rate have an irregular character (Fig.7). In the permafrost zone, this temporal variability of coastal erosion was established earlier (Vasiliev et al. 2001), whereas similar phenomena are known for areas without permafrost, such as Mexican Gulf, Baltic and Black Sea coasts (Yesin et al. 1980). In recent years, new data on temporal variations in the coastal retreat rate within the permafrost zone have been obtained (Brown et al. 2003). Neither the geological structure of the studied coast nor 
Fig. 7 Temporal changes in the retreat rate of cliff edge, MarreSale key site

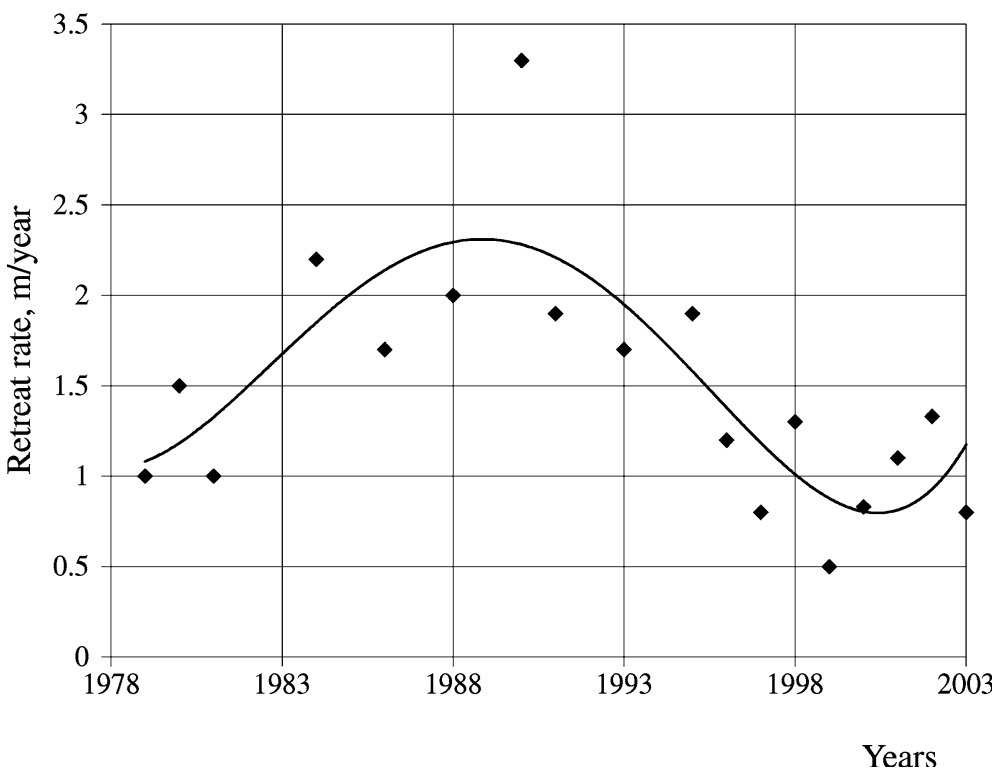

its cryogenic peculiarities can explain the observed temporal changes of coastal erosion.

It can be assumed that this phenomenon is related to the cyclicity in atmospheric circulation and hydrodynamic processes in the Arctic seas. The effect of local variations in hydro and meteorological conditions seems to be of lower importance for this cyclicity. From our point of view, such temporal variations in the coastal retreat rate are typical for the entire Arctic coast. This leads to speculation about whether or not patterns of temporal changes in the rates of coastal destruction under conditions of changing climate exhibit synchronicity over the entire circumpolar area. In turn, this problem is connected with a more general problem of the response of coastal dynamics to global climate change. It can be assumed that, for different regions of the Arctic, some shifts in the time, amplitude, and, probably, duration of particular phases of the cycles may take place. To assess these phenomena, we need to compare the results of relatively short-term (5-10 years) observations to the thermal erosion of coasts in several key sites in different Arctic regions. These observations should be made according to a standardized set of procedures, which would make intercomparison of results possible.

A generalized summary of observational data from the key sites is presented in Table 2. Available data make it possible to calculate the annual input of material into the sea from coastal erosion. This has been performed for the Kara Sea within the framework of the ACD program on the basis of the analysis of the GIS system, "Arctic Coast of Russia," which includes digitized maps of the relief, shoreline position, surface deposits, landscape characteristics, vegetation, and permafrost conditions. Arctic coasts have been segmented into relatively homogenous parts on the basis of analyses of these maps (Drozdov and Korostelev 2003). For the Kara sea, about 200 homogeneous sections of the

Table 2 Parameters of coastal conditions and the rates of coastal retreat at the key sites

\begin{tabular}{|c|c|c|c|c|c|c|c|c|c|c|}
\hline \multirow[t]{2}{*}{ Sea } & \multirow[t]{2}{*}{ Key site } & \multirow[t]{2}{*}{$\begin{array}{l}\text { Cliff } \\
\text { height (m) }\end{array}$} & \multirow[t]{2}{*}{ Deposits } & \multirow[t]{2}{*}{$C \operatorname{org}(\%)$} & \multirow[t]{2}{*}{$\begin{array}{l}\text { Volumetric } \\
\text { ice content }(\%)\end{array}$} & \multicolumn{2}{|c|}{ Seabed inclination } & \multicolumn{3}{|c|}{$\begin{array}{l}\text { Retreat rate } \\
\text { (m/year) }\end{array}$} \\
\hline & & & & & & Start part. & Mean & Max & Min & Mean \\
\hline \multirow[t]{4}{*}{ Kara Sea } & \multirow[t]{2}{*}{ Marre-Sale } & \multirow[t]{2}{*}{$15-30$} & Clays & 0.9 & $35-45$ & \multirow[t]{2}{*}{0.08} & \multirow[t]{2}{*}{0.003} & \multirow[t]{2}{*}{3.5} & \multirow[t]{2}{*}{0.5} & \multirow[t]{2}{*}{1.7} \\
\hline & & & Sands & 0.7 & $10-15$ & & & & & \\
\hline & \multirow[t]{2}{*}{ Cape Shpindler } & \multirow[t]{2}{*}{$20-45$} & Clays & 1,0 & $35-50$ & \multirow[t]{2}{*}{0.02} & \multirow[t]{2}{*}{0.007} & \multirow[t]{2}{*}{1.6} & \multirow[t]{2}{*}{0.9} & \multirow[t]{2}{*}{1,1} \\
\hline & & & Sands & 0,1 & & & & & & \\
\hline \multirow{4}{*}{ Barents Sea } & Cape Bolvansky & $20-30$ & Sands & 0.3 & 20 & 0.0003 & 0.0003 & 0.4 & 0.0 & $<0.1$ \\
\hline & \multirow{3}{*}{$\begin{array}{l}\text { Western shore } \\
\text { of Kolguev Island }\end{array}$} & \multirow[t]{3}{*}{$40-50$} & Clays & 0.8 & $<10$ & \multirow[t]{3}{*}{0.06} & \multirow[t]{3}{*}{0.004} & \multirow[t]{3}{*}{3.5} & \multirow[t]{3}{*}{0.6} & \multirow[t]{3}{*}{2.0} \\
\hline & & & Sands & 0.8 & 30 & & & & & \\
\hline & & & $\begin{array}{l}\text { Loams } \\
\text { with pebbles }\end{array}$ & 1.2 & $15-25$ & & & & & \\
\hline
\end{tabular}


coast have been distinguished. The total length of the coasts subjected to thermal erosion reaches $3200 \mathrm{~km}$ (the rest of the coasts are classified as either stable or aggradational coasts).

Calculations based on the segmentation map and classification table (Drozdov and Korostelev 2003) show that the bulk annual input of the material from the destruction of coastal cliffs into the Kara Sea reaches 35-40 million $\mathrm{t}$, including 7.5 million $\mathrm{t}$ of melting ice, 0.3 million $\mathrm{t}$ of $C_{\text {org }}$ contained in coastal sediments, 0.05 million $\mathrm{t}$ of $C_{\mathrm{org}}$ from the destruction of surface soil layer, and 0.3 million $t$ of soluble salts. These values are nearly 3 times lower than the results of approximate calculations carried out by Romankevich and Vetrov (2001). Annual loss of terrestrial land due to the retreat of coasts in the Kara Sea basin reaches 140 ha.

\section{Conclusions}

The results of observations of thermal erosion of the coasts at four ACD key sites in the basins of the Barents and Kara Seas allow the following conclusions to be drawn:

1. The depth of wave action on the sea bed reaches 4 $6 \mathrm{~m}$ in the Kara Sea and 8-10 $\mathrm{m}$ in the Barents Sea.

2. The seabed profiles for the coasts of thermo-erosion and erosion-accumulative origin differ only within those segments affected by wave action. Gentle slopes with smooth topography are formed due to a considerable input of sandy material. In the case of a deficit of sand, a hummocky microtopography is typical of the sea bottom near the shore.

3. Particular coastal degradation mechanisms are a function not only of the geological composition and ice content of coastal deposits but also of the peculiarities of hydrodynamic processes in the sea. A set of degradational processes may vary temporally. In areas with a very high ice content in the coastal deposits or with massive ice bodies, the retreat rate of the cliff edge may significantly exceed the average retreat rate of the coastline for a relatively long time.

4. Coastal deposits in the western sector of Russian Arctic are characterized by a low content of organic carbon: about $1 \%$ in clay sediments and not more than $0.7 \%$ in sands.

5. The rate of coastal erosion is strongly correlated with the energy of sea waves but the role of storms with high $(>1 \mathrm{~m})$ waves in the destruction of coasts is relatively small. Coastal retreat is caused mainly by thermal erosion of the cliff base. Thus, shoreline retreat in the western Russian Arctic is connected with classical erosion processes.

6. Calculations of the input of material from the destruction of coastal cliffs into the Kara Sea show that the bulk annual input reaches 35-40 million t, including 7.5 million $t$ of ice (melt), 0.35 million $t$ of organic carbon, and 0.3 million t of soluble salts.
Acknowledgments The authors express special thanks to all participants in the field expeditions from the Earth Cryosphere Institute SB RAS and VNIIOKEANGEOLOGIA and to staff members of the Department of Lithology and Geochemistry of VNIIOKEANGEOLOGIA for the analysis of samples. Valuable consultations during the preparation of this paper were rendered by Drs. Felix Are and Volker Rachold. This work was supported by the INTAS, Grant No. 01-2329.

\section{References}

Are FE (1998) Thermoerosion of the Laptev Sea shores and its contribution to the sea sediments balance (in Russian). Earth Cryosphere 2(1):55-61

Brown J, Jorgenson T, Smith O, Lee W (2003) Long-term rates of arctic coastal erosion, Elson Lagoon, Barrow, Alaska. In: Proceedings of the Eighth International Conference on Permafrost, 21-25 July 2003, Zurich vol 1. A.A. Balkema Publishers, pp 101-106

Drozdov DS, Korostelev YuV (2003) Environmental maps of the Russian Arctic as a base for the segmentation of the coastline and the analyses of coastal dynamics. In: Eighth international conference on permafrost extended abstracts on current research and newly available information, 20-25 July 2003, Zurich. Glaciology and Geomorphodynamics Group, Geography Department, University of Zurich, pp 27-28

Forman SL, Ingolfsson O, Manley WF, Lokrantz H (1999) Late quaternary stratigraphy of western Yamal Peninsula, Russia: new constraints on the configuration of the Eurasian ice sheet. Geology 27:807-810

Goldfarb YuI, Ezhova AB (1990) Relic tabular ground ice on Yugorsky Peninsula. In: Questions of evolution and development of permafrost, Yakutsk, pp 22-31

Hequette A, Barnes PW (1990) Coastal retreat and shoreface profile variations in the Canadian Beaufort Sea. Mar Geol 91:113-132

Kizyakov AI (2002) The destruction forms of the Kara Sea coast rich in tabular ground ice. In: Proceeding of the International Conference "Extreme Phenomena in Cryosphere: Basic and Applied Aspects". Pushchino, p 245

Leibman MO, Vasiliev AA, Rogov VV, Ingolfsson O (2000) Study of massive ground ice of Yugorsky Peninsula with crystallographic methods (in Russian). Earth Cryosphere 4(2):31-40

Pavlov AV, Vasiliev AA, Shur YuL (1995) Monitoring of permafrost conditions of the west part of the Yamal Peninsula. In: The 25th Arctic workshop. Laval University, Quebec, pp 144 147

Rachold V, Grigoriev MN, Are FE, Solomon S, Reimnitz E, Kassens E, Antonov M (2000) Coastal erosion vs. riverine sediment discharge in the Arctic shelf seas. Int $\mathbf{J}$ Earth Sci $89: 450-460$

Rachold V, Eicken H, Gordeev VV, Grigoriev MN, Hubberten HW, Lisitsin AP, Shevchenko VP, Schirmeister L (2003) Modern terrigenous carbon input to the Arctic Ocean. In: Stein R, Macdonald RW (eds) The Arctic Ocean organic carbon cycle: present and past. Springer, Berlin Heidelberg New York, pp $33-56$

Romankevich EA, Vetrov AA (2001) Cycle of carbon in the Russian Arctic seas (in Russian). Nauka, Moscow, p 302

Stein R, Macdonald RW (2003) Organic carbon budget Arctic ocean vs. global ocean. In: Stein R, Macdonald RW (eds) The organic carbon cycle in the Arctic Ocean. Springer, Berlin Heidelberg New York, pp 315-322

Vasiliev AA (2003) Permafrost controls of coastal dynamics at the Marre-Sale key site, western Yamal Peninsula, Siberia. In: Proceedings, eighth international conference on permafrost, 2125 July 2003, Zurich, vol 2. A.A. Balkema Publishers, pp 1173 1178

Vasiliev AA, Rogov VV (2001) Tabular ground ice in the MarreSale region: Yamal Peninsula. In: Proceedings of the 2nd 
Russian conference on permafrost (in Russian), vol 1, part 2. Moscow State University press, Moscow, pp 504-511

Vasiliev AA, Pokrovsky SI, Shur YuL (2001) Dynamics of the thermo-erosion shores of the Western Yamal (in Russian). Earth Cryosphere 5(1):44-52

Vasiliev AA, Kanevskiy MZ, Firsov YuG (2003) The mechanism of the seacoast destruction in Marre-Sale, Western Yamal. Rep Polar Mar Res 443:110-113
Velikotsky MA (1998) Peculiarities of recent dynamics of the shores of Kolguev Island. In: Dynamics of the Russian Arctic shore (in Russian). State University press, Moscow, pp 93-101 Yesin NV, Savin MT, Zhilyaev AP (1980) Abrasion process on the seashore (in Russian). Leningrad, Gidrometeoizdat, $200 \mathrm{pp}$ 